\title{
Tabes dorsalis - a disease that must not be forgotten
}

\author{
Wiąd rdzenia - choroba, o której nie można zapomnieć \\ Magda Marek-Safiejko, Agnieszka B. Serwin, Iwona Flisiak \\ Department of Dermatology and Venereology, Medical University of Bialystok, Poland \\ Klinika Dermatologii i Wenerologii Uniwersytetu Medycznego w Białymstoku, Polska
}

Dermatol Rev/Przegl Dermatol 2018, 105, 613-618 DOI: https://doi.org/l0.51 |4/dr.2018.79|73 CORRESPONDING AUTHOR/
ADRES DO KORESPONDENCJI:
Magda Marek-Safiejko
Klinika Dermatologii
i Wenerologii
Uniwersytet Medyczny
ul. Żurawia 14
15-540 Białystok
tel.: +48 604911814
e-mail: magdamarek83@gmail.com

\begin{abstract}
Introduction. The central nervous system can be invaded by Treponema pallidum at any stage of syphilis.

Objective. To present a case of tabes dorsalis, which developed in a patient with undiagnosed and untreated syphilis.

Case report. A 56-year-old woman was admitted because of positive serological tests for syphilis. The serological tests for syphilis titers in the patient's serum were: VDRL - 1/128, FTA - 1/36 000, FTA-ABS (+), TPHA $-1 / 81$ 920. Neurological and ophthalmic abnormalities were found. The VDRL test was negative and treponemal tests were positive in cerebrospinal fluid. Pleocytosis was normal. On the basis of history, clinical abnormalities and serological tests for syphilis, the diagnosis of tabes dorsalis was made. Treatment according to the European guidelines was administered. Six months later titers of serological tests for syphilis remained stable. Neurological abnormalities were partially reversed.
\end{abstract}

Conclusions. A lack of public mass screening for syphilis contributes to the presence of cases of late syphilis, including late neurosyphilis.

\section{STRESZCZENIE}

Wprowadzenie. Ośrodkowy układ nerwowy może ulec zakażeniu krętkiem bladym w każdym stadium kiły.

Cel pracy. Przedstawienie przypadku wiądu rdzenia w przebiegu nierozpoznanej i nieleczonej kiły.

Opis przypadku. Pacjentka, lat 56, hospitalizowana z powodu dodatniego wyniku odczynu USR. W surowicy stwierdzono: VDRL - 1/128, FTA - 1/36 000, FTA-ABS (+), TPHA - 1/81 920. Stwierdzono zniesienie odruchów głębokich z kończyn dolnych, lekko chwiejną próbę Romberga oraz leniwą reakcję źrenicy lewej na światło. W płynie mózgowo-rdzeniowym odczyn VDRL był ujemny, odczyny krętkowe dodatnie, a cytoza prawidłowa. Na podstawie wywiadu, odchylen w badaniach specjalistycznych oraz wyników odczynów serologicznych rozpoznano wiąd rdzenia. Włączono leczenie według zaleceń europejskich. Po 6 miesiącach obserwowano stabilizację mian odczynów serologicznych oraz częściowe ustąpienie objawów neurologicznych.

Wnioski. Zwiększający się współczynnik zapadalności na kiłę oraz brak powszechnych przesiewowych badań serologicznych powodują, że zdarzają się przypadki kiły późnej, w tym kiły ośrodkowego układu nerwowego. 
Key words: syphilis, tabes dorsalis, treatment, screening.

Słowa kluczowe: kiła, wiąd rdzenia, leczenie, kontrola.

\section{INTRODUCTION}

Treponema pallidum subspecies pallidum has a strong potential for tissue invasion and easily crosses the blood-cerebrospinal fluid barrier. The central nervous system (CNS) can be invaded at any stage of syphilis $[1,2]$. In early forms of neurosyphilis, invasion of the meninges and meningeal vessels can occur, which, in turn, can manifest as asymptomatic neurosyphilis, syphilitic meningitis, and meningovascular syphilis. Late forms of neurosyphilis, which result from an infection lasting many years and involvement of the cerebral and medullary parenchyma, manifest as progressive paralysis or tabes dorsalis [1-3]. Late neurosyphilis is observed in 5-10\% of untreated patients, which suggests the importance of the immune response in the elimination of T. pallidum from the CNS [4].

\section{OBJECTIVE}

To present a case of late neurosyphilis in a female patient, manifested as tabes dorsalis, as a result of undiagnosed infection lasting many years.

\section{CASE REPORT}

A 56-year-old female patient, a citizen of Chechnya, was admitted to the department in April 2016 due to a positive result of screening serological tests for syphilis (STS) conducted at a reception center for foreigners. The screening test also detected a previously undiagnosed hepatitis $\mathrm{C}$ virus (HCV) infection.

Taking detailed history was difficult due to the language barrier. Prior to admission, the patient had not been treated for any chronic diseases. She had not had any sexual relationships for nine years. Previously, the patient had been married three times and denied any casual sexual intercourse. She never noticed abnormalities within the urogenital organs or skin lesions in either herself or her partners.

During hospitalization at the department, very high treponemal and non-treponemal STS titers in serum were observed (table 1). Abolition of deep reflexes of the lower limbs, bilaterally weakly positive Babinski sign and slightly positive Romberg's test were found on neurological examination, while ophthalmologic examination revealed weak reaction to

\section{WPROWADZENIE}

Krętek blady (T. pallidum subspecies pallidum) odznacza się dużą zdolnością do inwazji tkanek i łatwo przenika przez barierę krew-płyn mózgowo-rdzeniowy. Do zakażenia ośrodkowego układu nerwowego (OUN) może dojść w każdym stadium kiły $[1,2]$. We wczesnych postaciach kiły OUN następuje zajęcie opon mózgowo-rdzeniowych oraz naczyń, co może skutkować bezobjawową kiłą OUN, kiłowym zapaleniem opon mózgowo-rdzeniowych oraz kiłą oponowo-naczyniową. Późne postaci kiły OUN, wynikające z wieloletniego zakażenia prowadzącego do zajęcia miąższu mózgu i rdzenia, objawiają się porażeniem postępującym (paralysis progressiva) oraz wiądem rdzenia (tabes dorsalis) [1-3]. Kiłę późną OUN obserwuje się u 5-10\% nieleczonych pacjentów, co sugeruje duże znaczenie odpowiedzi immunologicznej w procesie eliminacji T. pallidum z OUN [4].

\section{CEL PRACY}

Przedstawienie przypadku pacjentki, u której doszło do rozwoju kiły późnej OUN w postaci wiądu rdzenia $\mathrm{w}$ wyniku nierozpoznanego przez wiele lat zakażenia.

\section{OPIS PRZYPADKU}

Pacjentka, lat 56, obywatelka Czeczenii, została przyjęta do Kliniki w kwietniu 2016 r. z powodu dodatniego wyniku badania przesiewowego w kierunku kiły wykonanego w ośrodku dla cudzoziemców. $\mathrm{W}$ badaniu przesiewowym wykryto również niezdiagnozowane dotąd zakażenie wirusem zapalenia wątroby typu C (hepatitis C virus - HCV).

Bariera językowa utrudniała dokładne zebranie wywiadu. Dotychczas pacjentka nie leczyła się z powodu chorób przewlekłych. Nie utrzymywała kontaktów seksualnych od 9 lat. Wcześniej była trzykrotnie zamężna i negowała kontakty przygodne. Nigdy nie zauważyła zmian w obrębie narządów moczowo-płciowych ani zmian skórnych u siebie i partnerów.

Podczas hospitalizacji w klinice stwierdzono bardzo wysokie miana odczynów krętkowych i niekrętkowych w surowicy (tab. 1), w badaniu neurologicznym - zniesienie odruchów głębokich z kończyn dolnych, obustronnie słabo dodatni objaw Babińskiego oraz lekko chwiejną próbę Romberga, w badaniu 
Table I. Serological test results in patient's serum and cerebrospinal fluid

Tabela I. Wyniki odczynów serologicznych w surowicy i płynie mózgowo-rdzeniowym pacjentki

\begin{tabular}{|c|c|c|c|c|c|}
\hline Parameter/Parametr & & $\begin{array}{l}\text { May 2016/ } \\
\text { Maj 2016 r. }\end{array}$ & $\begin{array}{c}\text { June 2016/ } \\
\text { Czerwiec 2016 r. }\end{array}$ & $\begin{array}{l}\text { November 2016/ } \\
\text { Listopad } 2016 \text { r. }\end{array}$ & $\begin{array}{l}\text { March 2017/ } \\
\text { Marzec } 2017 \text { r. }\end{array}$ \\
\hline Serum/Surowica & $\begin{array}{l}\text { VDRL } \\
\text { FTA } \\
\text { FTA-ABS } \\
\text { TPHA }\end{array}$ & $\begin{array}{c}1 / 128 \\
1 / 36000 \\
1 / 10 \\
1 / 81920\end{array}$ & I/I28 & $\begin{array}{c}1 / 128 \\
1 / 24000 \\
(+) \\
1 / 81920\end{array}$ & $1 / 128$ \\
\hline $\begin{array}{l}\text { Cerebrospinal fluid/ } \\
\text { Płyn mózgowo-rdzeniowy }\end{array}$ & $\begin{array}{l}\text { VDRL } \\
\text { FTA } \\
\text { TPHA }\end{array}$ & $\begin{array}{c}(-) \\
1 / 450 \\
1 / 10240\end{array}$ & & $\begin{array}{c}(-) \\
\text { I/450 } \\
1 / 10240\end{array}$ & \\
\hline
\end{tabular}

light of the left pupil. No abnormalities on cardiological and dermatological examinations were found.

The above abnormalities were an indication for lumbar puncture. No abnormalities were detected in a general cerebrospinal fluid examination, but positive results of treponemal tests were obtained (table1). Moreover, an increased titer of IgG antibodies against Chlamydia trachomatis (14.3 NTU; results > 11.5 NTU considered as elevated) was found in serum. HIV-1 and HIV-2 infections, gonorrhea and trichomoniasis were excluded. High activities of alanine aminotransferase (ALT) $(143 \mathrm{U} / 1$, normal values < $41 \mathrm{U} / \mathrm{l})$ and aspartate aminotransferase (AST) (105 U/1, normal values < $32 \mathrm{U} / 1)$ were detected. After hepatological consultation, the patient was referred for further specialist diagnostics.

On the basis of epidemiological history, abnormalities in specialist examinations and the positive results of serological tests for syphilis (STS) in serum and in cerebrospinal fluid, tabes dorsalis was diagnosed. Due to the lack of benzyl penicillin, second-line treatment was administered: ceftriaxone at $2.0 \mathrm{~g} /$ day i.v., in accordance with the European Guideline on the Management of Syphilis [5]. After completion of the syphilis treatment, chlamydial infection was treated with doxycycline at $0.2 \mathrm{~g} /$ day for 7 days.

One and six months after the end of treatment, the VDRL test titer in serum remained unchanged (the patient failed to report for scheduled follow-up visits). No decrease in the STS titers was seen in cerebrospinal fluid examination conducted 6 months after treatment (table 1). Romberg's test and Babinski sign became negative on neurological examination, but the abolition of deep reflexes of the lower limbs was maintained. The decision of retreatment was made. In February 2017, when benzyl penicillin was available, the patient was treated with it at the dose of $6 \times 4 \mathrm{MU} /$ day i.v. for 14 days. In the last serological test conducted in March 2017, the VDRL test titer remained unchanged. The patient left Poland and did not report for subsequent follow-up visits. It was impossible to examine the sexual partners of the patient. okulistycznym - leniwą reakcję na światło źrenicy oka lewego. Nie wykazano odchyleń od normy w badaniu kardiologicznym i dermatologicznym.

Powyższe odchylenia były wskazaniem do wykonania punkcji lędźwiowej. W badaniu ogólnym płynu mózgowo-rdzeniowego nie było odchyleń od normy, stwierdzono natomiast dodatnie wyniki odczynów krętkowych (tab. 1). Ponadto w surowicy wykazano podwyższone miano przeciwciał przeciwko Chlamydia trachomatis w klasie IgG (14,3 NTU; wynik dodatni $>$ 11,5 NTU). Wykluczono zakażenie HIV-1 i HIV-2, rzeżączkę i rzęsistkowicę. Stwierdzono wysoką aktywność aminotransferazy alaninowej (ALT) - 143 U/1 (norma: < $41 \mathrm{U} / 1$ ) i aminotransferazy asparaginianowej (AST) - 105 U/1 (norma: < 32 U/1). Po konsultacji hepatologicznej pacjentkę skierowano do dalszej diagnostyki.

Na podstawie wywiadu epidemiologicznego, odchyleń w badaniach specjalistycznych oraz dodatnich wyników odczynów serologicznych w surowicy i płynie mózgowo-rdzeniowym rozpoznano wiąd rdzenia. Ze względu na brak penicyliny krystalicznej włączono leczenie drugiego wyboru: ceftriakson $\mathrm{w}$ dawce 2,0 g/ dobę dożylnie zgodnie z zaleceniami europejskimi [5]. Po zakończeniu terapii kiły rozpoczęto leczenie zakażenia chlamydialnego doksycykliną $\mathrm{w}$ dawce 0,2 g/dobę przez 7 dni.

Po miesiącu i 6 miesiącach od zakończenia leczenia miano odczynu VDRL w surowicy było bez zmian (chora nie zgłaszała się regularnie na wyznaczone kontrole). Po 6 miesiącach wykonano kontrolne badanie w płynie mózgowo-rdzeniowym i nie obserwowano zmniejszenia się mian odczynów (tab. 1). Podczas ponownej konsultacji neurologicznej stwierdzono ujemną próbę Romberga, ujemny objaw Babińskiego, ale utrzymujący się zanik odruchów głębokich z kończyn dolnych. Zdecydowano o ponownej antybiotykoterapii (luty 2017 r.). Zastosowano dostępną już penicylinę krystaliczną w dawce $6 \times 4 \mathrm{mln}$ j./dobę i.v. przez 14 dni. W ostatnim badaniu serologicznym wykonanym w marcu 2017 r. miano odczynu VDRL się nie zmieniło. Pacjentka opuściła Polskę i nie zgłosiła się na kolejne kontrole. Niemożliwe było zbadanie partnerów seksualnych pacjentki. 


\section{DISCUSSION}

The present case is worth reviewing for at least two reasons. First, descriptions of cases of tabes dorsalis from European centers are rare [6-8]. In studies by Danish and Dutch authors, late parenchymal syphilis of the CNS was diagnosed relatively frequently, as opposed to studies by Spanish authors [6-8]. Second, two other sexually transmissible infections - chlamydial infection (asymptomatic) and HCV were found in the patient. Moreover, the ambiguity of the serological response after the treatment of late neurosyphilis is noteworthy [5].

Tabes dorsalis usually develops after 20-25 years of untreated syphilis, and its symptoms are a result of damage of the posterior roots and columns of the spinal cord. At an early stage of the disease, paresthesia, weakening or abolition of deep reflexes of the lower limbs, weakening of the pupil accommodation to light, and shooting pain (sudden attacks of limb or epigastric pain, associated with nausea and vomiting) are observed. At an advanced stage, functional disturbances of sphincters and erectile dysfunction occur. The damage can also affect the cranial nerves, particularly II, III and VI, leading to e.g. blindness and deafness [1]. Some of these symptoms were observed in the present patient.

Cerebrospinal fluid examination is of key importance in the diagnosis of CNS syphilis. The examination must be conducted in all patients diagnosed with syphilis in whom abnormalities have been found in neurological, ophthalmological, psychiatric or laryngological examinations regardless of the duration of syphilis, and in all patients with tertiary syphilis [5]. Lack of an appropriate serological response after syphilis treatment, as well as alternative (tetracycline-based) treatment of late syphilis, can also be an indication for lumbar puncture [6-8]. In cerebrospinal fluid, a protein concentration assessment, mononuclear cell count, as well as non-treponemal (VDRL) and treponemal (TPHA, FTA, FTA-ABS) tests, must be assessed [5]. In parenchymal forms of CNS syphilis, the protein concentration and mononuclear cell count can be normal, as was observed in the present patient [5]. The VDRL titer in cerebrospinal fluid is positive only in $1 / 3$ of CNS syphilis patients, but it is a sufficient single criterion for the diagnosis of neurosyphilis due to its high specificity $[9,10]$. The TPHA test is usually positive in neurosyphilis, but it is not sufficient to diagnose neurosyphilis. However, a negative result of this test allows CNS syphilis to be excluded with a high probability [2]. In the cerebrospinal fluid of the present patient, a negative VDRL test and a very high TPHA test titer were observed, which allowed the diagnosis of parenchymal neurosyphilis together with the results of specialist examinations and positive STS results in serum.

\section{OMÓWIENIE}

Przedstawiony przypadek zasługuje na zainteresowanie z kilku powodów. Po pierwsze, opisy przypadków wiądu rdzenia z ośrodków europejskich są rzadkie [6-8]. W badaniach autorów duńskich i holenderskich kiła późna miąższowa OUN była diagnozowana stosunkowo często $\mathrm{w}$ przeciwieństwie do badań autorów hiszpańskich [6-8]. Po drugie, u chorej współwystępowały dwa inne zakażenia przenoszone drogą płciową - zakażenie chlamydialne (bezobjawowe) i zakażenie HCV. Na uwagę zasługują także dylematy w ocenie odpowiedzi serologicznej po leczeniu kiły późnej OUN [5].

Wiąd rdzenia pojawia się zwykle po 20-25 latach nieleczonej kiły, a jego objawy wynikają z uszkodzenia korzeni oraz sznurów tylnych rdzenia kręgowego. We wczesnym etapie choroby obserwuje się parestezje, osłabienie lub zniesienie odruchów głębokich kończyn, osłabienie reakcji źrenicy na światło oraz tzw. bóle strzelające (nagłe napady bólu kończyn lub innych części ciała, np. nadbrzusza, z towarzyszącymi nudnościami i wymiotami). W zaawansowanej postaci dołączają się zaburzenia czynności zwieraczy oraz erekcji. Uszkodzenie może dotyczyć również nerwów czaszkowych, zwłaszcza II, III, VI, co prowadzi m.in. do ślepoty i głuchoty [1]. Część tych objawów obserwowano u opisywanej pacjentki.

W rozpoznaniu kiły OUN podstawowe znaczenie ma badanie płynu mózgowo-rdzeniowego. Należy je wykonać u wszystkich pacjentów z rozpoznaną kiłą, $\mathrm{u}$ których stwierdzono odchylenia $\mathrm{w}$ badaniu neurologicznym, okulistycznym, psychiatrycznym lub laryngologicznym, niezależnie od okresu kiły, a także u wszystkich pacjentów z kiłą trzeciego okresu [5]. Brak prawidłowej odpowiedzi serologicznej po leczeniu kiły oraz terapia kiły późnej alternatywnie - tetracyklinami, może również być wskazaniem do wykonania punkcji lędźwiowej [6-8]. W płynie mózgowo-rdzeniowym należy oznaczyć stężenie białka, liczbę komórek jednojądrowych oraz wykonać odczyny niekrętowe (VDRL) i krętkowe (TPHA, FTA, FTA-ABS) [5]. W postaciach miąższowych kiły OUN stężenie białka oraz liczba komórek jednojądrowych mogą być prawidłowe, co obserwowano u prezentowanej chorej [5]. Odczyn VDRL jest dodatni $\mathrm{w}$ płynie mózgowo-rdzeniowym tylko u 1/3 chorych z kiłą OUN, ale jest wystarczającym, samodzielnym kryterium rozpoznania kiły późnej OUN ze względu na dużą swoistość [9, 10]. Odczyn TPHA jest zazwyczaj dodatni w kile OUN, ale nie wystarcza do jej rozpoznania, natomiast wynik ujemny z dużym prawdopodobieństwem ją wyklucza [2]. W płynie mózgowo-rdzeniowym opisywanej chorej uzyskano ujemny odczyn VDRL, ale bardzo wysokie miano odczynu TPHA, co w kontekście wyników badań specjalistycznych i dodatnich odczynów w surowicy pozwoliło rozpoznać kiłę miąższową OUN. 
According to the European Guideline on the Management of Syphilis, the treatment of choice in CNS syphilis, including that affecting the vision and hearing apparatuses, is benzyl penicillin at a dose of 18$24 \mathrm{MU} /$ day i.v. in subdoses every 4 hours for 10-14 days. The second-line treatment is ceftriaxone, which also penetrates well into the cerebrospinal fluid, at the dose of 1.0-2.0 g/day i.v. for 10-14 days, and procaine penicillin 1.2-2.4 MU/day i.m. with probenecid $2 \mathrm{~g} /$ day in 4 doses administered over 10-14 days [5, 11].

Re-examination of the cerebrospinal fluid should be conducted 6 weeks to 6 months after the completed treatment [5]. Results of treponemal tests can remain positive for the rest of the patient's life. After the treatment of late syphilis, as opposed to the treatment of early syphilis, a decline in titers of serological tests should not be expected, as we observed in the present patient [5].

Since changes occurring in the parenchyma of the spinal cord in the course of tabes dorsalis are primarily of a destructive nature, and to a lesser degree of an inflammatory nature, they are irreversible or poorly reversible despite successful antitreponemal treatment [1]. Indeed, a follow-up neurological examination of the present patient conducted six months after treatment revealed incomplete resolution of abnormalities.

\section{CONCLUSIONS}

Tabes dorsalis should have been a rare condition since the introduction of effective antibiotic therapy for syphilis. However, the incidence rate of acquired syphilis that has been increasing for a few years in Europe [12], lack of population-based screening, and significant migration can contribute to the delay in diagnosis of syphilis and development of late CNS syphilis. Quick laboratory diagnostics and implementation of appropriate treatment could prevent irreversible changes in the CNS that can pose a serious risk to the health and life of patients. The present case indicates the need to diagnose other sexually transmitted infections in every patient with newly diagnosed syphilis.

\section{CONFLICT OF INTEREST}

The authors declare no conflict of interest.
Zgodnie z zaleceniami europejskimi lekiem z wyboru w leczeniu kiły OUN, w tym kiły narządu wzroku i słuchu, jest penicylina benzylowa (krystaliczna) w dawce 18-24 mln j./dobę i.v. w dawkach podzielonych co 4 godziny przez 10-14 dni. Lekami drugiego wyboru są ceftriakson, w dawce 1,0-2,0 g/dobę i.v. przez 10-14 dni, który również dobrze przenika do płynu mózgowo-rdzeniowego, oraz penicylina prokainowa w dawce 1,2-2,4 mln j./ dobę i.m. z probenecydem $2 \mathrm{~g} /$ dobę w 4 dawkach podzielonych przez 10-14 dni $[5,11]$.

Ponowne badanie płynu mózgowo-rdzeniowego powinno się odbyć po 6 tygodniach do 6 miesięcy od zakończonego leczenia [5]. Dodatnie wyniki odczynów krętkowych mogą się utrzymywać do końca życia. W kile później nie należy się spodziewać obniżenia mian odczynów serologicznych takiego jak po leczeniu kiły wczesnej, co obserwowano u opisanej chorej [5].

Zmiany powstałe $\mathrm{w}$ zakresie miąższu rdzenia kręgowego w przebiegu wiądu rdzenia mają przede wszystkim charakter destrukcyjny, a w mniejszym stopniu zapalny, dlatego pomimo skutecznego leczenia przeciwkrętkowego są nieodwracalne lub odwracalne w niewielkim stopniu [1]. Również w przypadku opisywanej pacjentki w kontrolnym badaniu neurologicznym 6 miesięcy po leczeniu odchylenia od normy nie cofnęły się całkowicie.

\section{WNIOSKI}

Od czasu wprowadzenia skutecznej antybiotykoterapii do leczenia kiły wiąd rdzenia powinien być rzadkością. Zwiększający się od kilku lat współczynnik zapadalności na kiłę nabytą w Europie [12], brak powszechnych badań przesiewowych oraz znaczne ruchy migracyjne mogą się przyczyniać do opóźnionego rozpoznania kiły i rozwoju kiły późnej OUN. Szybka diagnostyka i wdrożenie prawidłowego leczenia pozwoliłoby zapobiec powstawaniu nieodwracalnych zmian w OUN, które mogą stanowić poważne zagrożenie dla zdrowia i życia chorych. Prezentowany przypadek podkreśla konieczność diagnozowania innych zakażeń przenoszonych drogą płciową u każdego pacjenta z nowo rozpoznaną kiłą.

\section{KONFLIKT INTERESÓW}

Autorzy nie zgłaszają konfliktu interesów.

\section{References}

\section{Piśmiennictwo}

1. Chodynicka B., Serwin A.B., Klepacki A.: Kiła. [In:] Choroby przenoszone drogą płciową. T.F. Mroczkowki (ed.). Czelej, Lublin, 2012, 149-201.

2. Lukehart S.A., Hook E.W., Baker-Zander S.A., Collier A.C., Critchlow C.W., Handsfield H.H.: Invasion of the central nervous system by Treponema pallidum: implications for diagnosis and treatment. Ann Intern Med 1988, 109, 855-862. 
3. Ghanem K.G.: Neurosyphilis: a historical perspective and review. CNS Neurosci Ther 2010, 16, 157-168.

4. Clark E.G., Danbolt N.: The Oslo study of the natural history of untreated syphilis; an epidemiologic investigation based on a restudy of the Boeck Bruusgaardmaterial; a review and appraisal. Chronic Dis 1955, 2, 311-344.

5. Janier M., Unemo M., Dupin N., Tiplica G.S., Patel R.: 2014 European guideline on the management of syphilis: giving evidence priority. J Eur Acad Dermatol Venereol 2016, 30, 78-79.

6. Conde-Sendín M.A., Amela-Peris R., Aladro-Benito Y., Maroto A.A.: Current clinical spectrum of neurosyphilis in immunocompetent patients. Eur Neurol 2004, 52, 29-35.

7. Danielsen A.G., Weismann K., Jørgensen B.B., Heidenheim M., Fugleholm A.M.: Incidence, clinical presentation and treatment of neurosyphilis in Denmark 1980-1997. Acta Derm Venereol 2004, 84, 459-462.

8. Daey Ouwens I.M., Koedijk F.D., Fiolet A.T., van Veen M.G., van den Wijngaard K.C., Verhoeven W.M., et al.: Neurosyphilis in the mixed urban-rural community of the Netherlands. Acta Neuropsychiatr 2014, 26, 186-192.

9. Larsen S.A., Hambie E.A., Wobig G.H., Kennedy E.J.: Cerebrospinal fluid serologic test for syphilis: treponemal and nontreponemal tests. [In:] Advances in Sexually Transmitted Diseases. R. Morriset, E. Kurstak (eds). VNU Science Presss, Utrecht, 1986, 157-162.

10. Marra C.M., Tantalo L.C., Maxwell C.L., Ho E.L., Sahi S.K., Jones T.: The rapid plasma reagin test cannot replace the venereal disease research laboratory test for neurosyphilis diagnosis. Sex Transm Dis 2012, 39, 453-457.

11. Shann S., Wilson J.: Treatment of neurosyphilis with ceftriaxone. Sex Transm Infect 2003, 79, 415-416.

12. https://ecdc.europa.eu/en/surveillance-atlas-infectious-diseases

Received: 11.03 .2018

Accepted: 22.07 .2018

Otrzymano: $11.03 .2018 \mathrm{r}$

Zaakceptowano: $22.07 .2018 \mathrm{r}$.

How to cite this article

Marek-Safiejko M., Serwin A.B., Flisiak I.: Tabes dorsalis - a disease that must not be forgotten. Dermatol Rev/Przegl Dermatol 2018, 105, 613-618. DOI: https://doi.org/10.5114/dr.2018.79173. 